\title{
Physico-Chemical Studies of Experimental Lots of Products, Obtained by Birch Wood Complex Processing on a Pilot Plant
}

\author{
Ivan P. Ivanov, Mikhail Yu. Belash*, \\ Nikolay V. Chesnokov and Boris N. Kuznetsov \\ Institute of Chemistry and Chemical Technology SB RAS \\ FRC "Krasnoyarsk Science Center SB RAS" \\ 50/24 Akademgorodok, Krasnoyarsk, 660036, Russia
}

Received 27.03.2017, received in revised form 30.04.2017, accepted 03.06.2017

The physico-chemical studies of experimental batches of microcrystalline cellulose (MCC), glucose hydrolyzate and soluble lignin, obtained from birch wood in a pilot plant were carried out. It was shown that the properties of experimental batches of MCC, glucose hydrolyzate and soluble lignin correspond to samples obtained from birch wood under laboratory conditions.

The yield of MCC with a residual lignin content no more than 1 mas. \% reaches $70 \%$ from the mass at initial cellulose in wood. The characteristics of obtained MCC corresponds to industrial microcrystalline cellulose. The degree of polymerization of the MCC sample is of 655, its crystallinity index of 0.73 , the crystallite size of $3.2 \mathrm{~nm}$.

Glucose hydrolysates for bioethanol synthesis were obtained by MCC hydrolysis with concentrated sulfuric acid at $25{ }^{\circ} \mathrm{C}$. It was established that the composition of experimental batch of glucose hydrolyzate (glucose content-83.2 mas. \%, of furfural-0.22 mg / ml, 5-HMF-0.48 mg / ml, levulinic acid - trace amount) corresponds to composition of laboratory samples of hydrolysates.

The side product lignin has an elemental composition (mas. \%): $\mathrm{C}-58.84, \mathrm{H}-5.81, \mathrm{O}-35.15$; ash content of 0.94, softening temperatures $115-138^{\circ} \mathrm{C}$. Lignin can be used for obtaining enterosorbents and nanoporous carbon sorbents, as well as a binder for briquetted biofuels.

Obtained results have been used for the development of technological regulations of birch wood complex processing to biofuels and chemicals.

Keywords: birch wood, pilot plant, pilot batches, microcrystalline cellulose, glucose hydrolyzate, soluble lignin.

DOI: $10.17516 / 1998-2836-0024$.

(C) Siberian Federal University. All rights reserved

* Corresponding author E-mail address: belash_mikhail@mail.ru 


\title{
Физико-химические исследования \\ опытных партий продуктов, полученных \\ при комплексной переработке древесины березы \\ на пилотной установке
}

\author{
И.П. Иванов, М.Ю. Белаш, \\ Н.В. Чесноков, Б.Н. Кузнецов \\ Институт химии и химической технологии СО РАН \\ ФИЦ «Красноярский научный центр СО РАН» \\ Россия, 660036, Красноярск, Академгородок, 50/24
}

Проведены физико-химические исследования опытных партий микрокристаллической целлюлозы (МКЦ), глюкозного гидролизата и растворимого лигнина, полученных из древесины березы на пилотной установке. Показано, что по своим свойствам опытные партии МКЦ, глюкозного гидролизата и растворимого лигнина соответствуют образцам, извлеченным из древесины березы в лабораторных условиях.

Выход МКЦ с содержанием остаточного лигнина не более 1 мас. \% составил 70 \% от массы исходной целлюлозы в древесине. Полученная МКЦпо своим характеристикам соответствует промыиленной микрокристаллической целлюлозе. Степень полимеризации образца МКЦ 655 , индекс кристалличности 0,73, размер кристаллитов 3,2 нм.

Гидролизом МКЦ концентрированной серной кислотой при $25{ }^{\circ} \mathrm{C}$ получень глюкознье гидролизать для синтеза биоэтанола. Установлено, что опьтная партия глюкозного гидролизата по своему составу (выход глюкозы - 83,2 мас. \%, наличие примесей фурфурола0,22 мг/мл, 5-ГМФ-0,48 мг/мл, левулиновой кислоты - следовое количество), соответствует средним значениям показателей лабораторных образцов гидролизатов.

Образующийся в качестве побочного продукта лигнин имеет элементный состав (мас. \%): $\mathrm{C}-58,84, \mathrm{H}-5,81, \mathrm{O}-35,15$; зольность 0,94 и интервал температур размягчения $115-138^{\circ} \mathrm{C}$. Лигнин может использоваться для получения энтеросорбентов и нанопористых углеродных сорбентов, а также в качестве связующего для брикетирования биотоплив.

Результаты исследований использованы для разработки технологического лабораторного регламента комплексной переработки биомассы березы в биотоплива и химические продукты.

Ключевые слова: древесина березы, пилотная установка, опытные партии, микрокристаллическая иееллюлоза, глюкозный гидролизат, растворимый лигнин.

\section{Введение}

В настоящее время в развитых странах мира реализуется стратегия расширенного использования возобновляемого растительного сырья как альтернативы ископаемым видам топлива. 
В России сосредоточено около 23 \% лесных ресурсов планеты, причем значительная их часть представлена березой, которая относится к низкосортным видам древесных пород. При заготовке, механической и химической переработке древесины образуется огромное количество древесных отходов. Древесные отходы создают надежную сырьевую базу для крупномасштабного производства химических продуктов и альтернативных топлив из возобновляемого сырья.

В последние годы в мире формируется промышленность по производству спиртовых топлив - преимущественно биоэтанола из непищевого лигноцеллюлозного сырья, к которому относится древесина [1]. Традиционные технологии гидролиза древесины не отвечают современным требованиям по производительности, энергопотреблению, ресурсосбережению и экологической чистоте. Перспективные направления исследований в создании принципиально новых технологий получения из лигноцеллюлозного сырья биотоплив и ценных химических продуктов ориентированы на комплексную безотходную переработку всех основных компонентов лигноцеллюлозной биомассы $[2,3]$.

Одним из ключевых процессов в развиваемых передовых технологиях комплексной переработки лигноцеллюлозной биомассы является ее фракционирование на полисахариды, лигнин, экстрактивные вещества. Их дальнейшая переработка в интегрированном технологическом цикле в биотоплива и ценные химические вещества способствует снижению затрат на единицу продукции и уменьшение загрязнения окружающей среды. Данное направление исследований (т.н. биорефайнери) интенсивно развивается в последние годы в Европе и в США $[4,5]$.

Как известно, древесина березы обладает большим количеством гемицеллюлоз (30 \% по массе) и высокой плотностью, что затрудняет применение традиционных технологий для получения из нее целлюлозы. Это обстоятельство делает актуальным постановку исследований по созданию новых методов глубокой переработки древесины березы. В работах [6-9] показана возможность эффективного разделения древесины березы на полисахариды и лигнин путем ее пероксидной делигнификации в среде “уксусная кислота-вода”. Варьирование температуры, концентрации пероксида водорода, уксусной кислоты, гидромодуля и продолжительности процесса с применением катализатора позволяет регулировать выход и состав получаемой целлюлозы и растворимых продуктов. В оптимальных условиях каталитического окисления древесины может быть получена целлюлоза, практически не содержащая остаточного лигнина. Для создания технологических основ процесса комплексной переработки древесины березы в ассортимент востребованных продуктов необходимо осуществить оптимизацию отдельных стадий процесса. Ранее с использованием результатов лабораторных исследований была проведена оптимизация процесса пероксидного фракционирования древесины березы на микрокристаллическую целлюлозу и растворимый лигнин [8], а также процесса гидролиза МКЦ концентрированной серной кислотой с получением глюкозных гидролизатов для синтеза биоэтанола [10].

Целью настоящей работы являлось осуществление экспериментальной оптимизации на пилотной установке отдельных стадий процесса комплексной переработки древесины березы, наработка при оптимальных режимах опытных партий МКЦ, глюкозного гидролизата и растворимого лигнина и изучение их физико-химических свойств. 


\section{Экспериментальная часть}

При разработке и создании пилотной установки по комплексной переработке биомассы березы были использованы технические решения, которые соответствуют критериям “зеленой” химии. При создании установки был реализован принцип блочно-модульного построения частей установки на основе стандартизации и унификации комплектующих изделий, материалов и сырья отечественного производства.

На рис. 1 представлен общий вид технологической части пилотной установки по комплексной переработке древесины березы. Пилотная установка состоит из следующих основных узлов:

1. Узел наработки технологических фракций древесины березы.

В составе узла наработки технологических фракций древесины березы используют следующее технологическое оборудование: короотделительная машина, роторная ножевая мель-

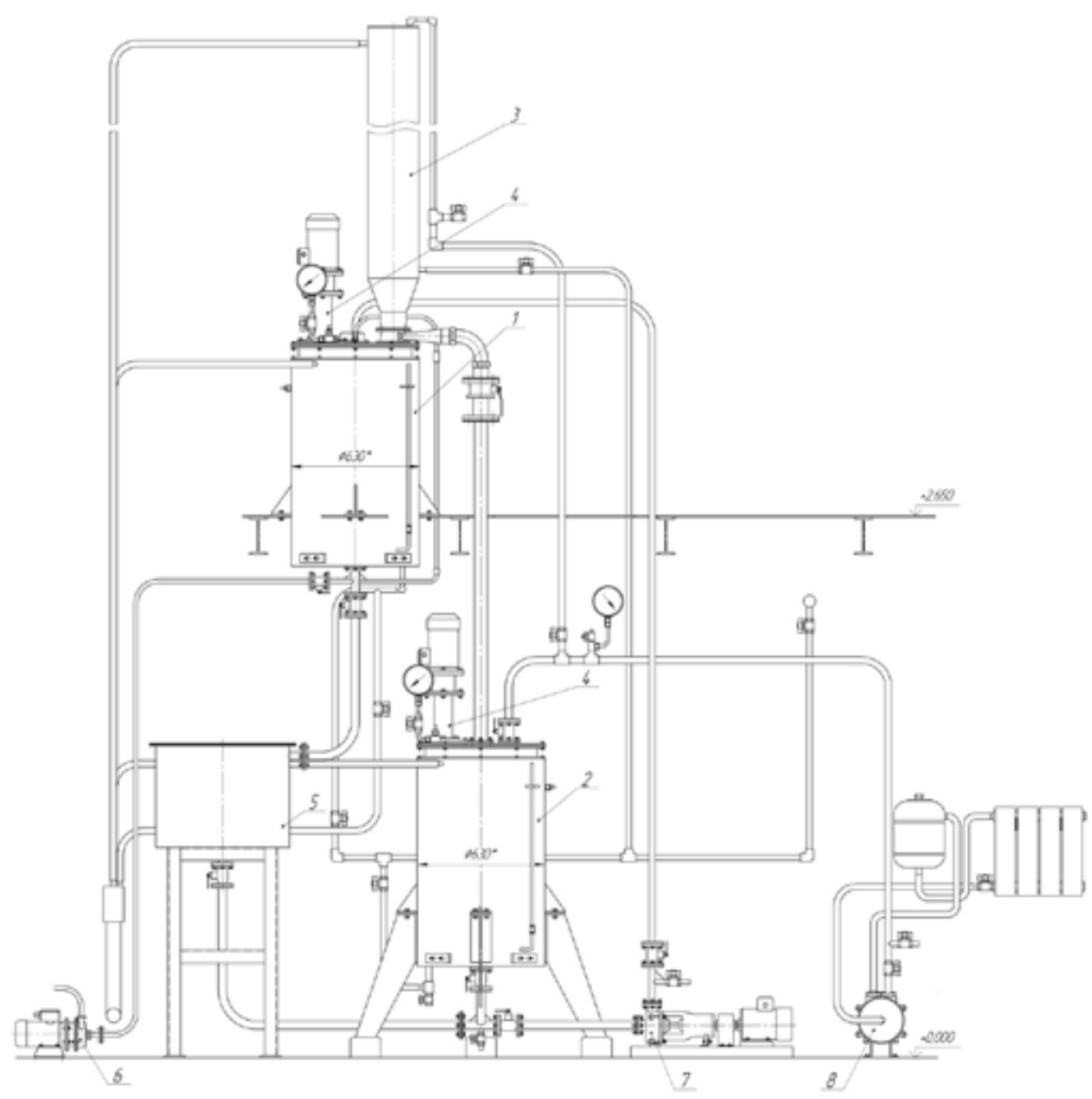

Рис. 1. Общий вид технологической части пилотной установки по комплексной переработке древесины березы: 1 - реактор-перколятор; 2 - реактор-концентратор; 3 - холодильник-конденсатор; 4 - мешалки турбинного типа; 5 - вакуумный нутч-фильтр; 6,7 - центробежные химические насосы; 8 - вакуумный водокольцевой насос 
ница РМ-120, просеивающая машина ГР-30 и сушильный шкаф с принудительной вентиляцией SNOL 120/300 LFN.

Для подготовки технологических фракций древесины березы исходное сырье подвергают предварительной сушке в сушильном шкафу до требуемой влажности, затем древесину березы направляют на измельчение в роторную мельницу и просеивающую машину для получения технологической фракции.

2. Узел переработки древесины березы.

В составе узла переработки древесины березы имеется следующее технологическое оборудование: два реактора (верхний и нижний), оборудованные мешалками турбинного типа, холодильник-конденсатор, химические центробежные насосы во взрывозащищенном исполнении, вакуумный нутч-фильтр ( $\mathrm{V}=150$ л).

3. Узел получения глюкозных гидролизатов.

В составе узла получения глюкозных гидролизатов используется следующее технологическое оборудование: барабанная шаровая мельница МШЛ-1 (гидролизер), инвертор Abat КПЭМ-60-ОМР, вакуумный нутч-фильтр ( $\mathrm{V}=30$ л), приемная емкость ( $\mathrm{V}=60$ л), химический центробежный насос, кислотный насос, дозатор шнековый.

4. Узел кондиционирования продуктов и полупродуктов.

В составе узла кондиционирования продуктов и полупродуктов присутствует вышеописанное оборудование по наработке технологических фракций совместно с дисковым истирателем ИДА-175 и сушильным вакуумным шкафом UT - 4660V.

В качестве исходного сырья для получения опытных партий продуктов брали древесину березы повислой (Betula Pendula Roth.), произрастающей в Красноярском крае. Содержание основных компонентов древесины березы представлены в табл. 1.

Для наработки опытных партий продуктов на пилотной установке использовали опилки древесины березы.

Для их получения высушенную в сушильном шкафу SNOL 120/300 LFN древесину березы измельчали в роторной ножевой мельнице РМ-120. Затем на просеивающей машине ГР-30 выделяли технологическую фракцию крупностью 2-5 мм и проводили ее сушку в сушильном шкафу до остаточной влажности 4-5 мас. \%.

\section{Получение опытной партии микрокристаллической целлюлозы (МКЦ)}

Наработку опытной партии МКЦ из древесины березы осуществляли по методике, ранее используемой в лабораторных условиях [9].

Таблица 1. Химический состав древесины березы

\begin{tabular}{|c|c|c|c|c|c|}
\hline \multirow{2}{*}{ Сырье } & \multicolumn{5}{|c|}{ Состав, \% от массы а.с.д. } \\
\cline { 2 - 6 } & Целлюлоза & Лигнин & Гемицеллюлозы & $\begin{array}{c}\text { Экстрактивные } \\
\text { вещества }\end{array}$ & Зола \\
\hline $\begin{array}{c}\text { Древесина } \\
\text { березы }\end{array}$ & 46,8 & 21,7 & 27,3 & 3,5 & 0,34 \\
\hline
\end{tabular}

* абсолютно сухой древесины. 
Высушенную технологическую фракцию древесины березы массой 8 и 0,08 кг катализатоpa $\mathrm{TiO}_{2}$ загружали в верхний реактор 1 (рис. 1), насосом подавали в него заранее приготовленный реакционный раствор объемом 119,4 л, содержащий 76,0 л воды; 30,4 л ледяной уксусной кислоты; 13,0 л 35 мас. \% пероксида водорода. После окончания загрузки включали мешалку турбинного типа 4 и обогрев реактора.

Температуру в реакторе поддерживали на уровне $98-100{ }^{\circ} \mathrm{C}$ при помощи измерителярегулятора ТРМ-1 в течение 4 ч. При этом происходит практически полное удаление лигнина из древесных опилок и его переход в раствор. Для отделения полученной целлюлозы от лигнинсодержащего варочного раствора проводили его горячее фильтрование при температуре $75-80{ }^{\circ} \mathrm{C}$ на вакуумном нутч-фильтре 5 с рабочим объемом 150 л. Для этого открывали кран слива с верхнего реактора 1 и варочный раствор переливали в нутч-фильтр 5. Включали вакуумный водно-кольцевой насос 8 и на фильтрующем элементе фильтра производили отделение микрокристаллической целлюлозы от варочного раствора.

Полученный фильтрат варочного раствора перекачивали в нижний реактор 2 для проведения процесса регенерации уксусной кислоты.

Образующиеся пары уксусной кислоты по паропроводу поступали в холодильникконденсатор 3, откуда в виде флегмы стекали в верхний реактор 1. Полученная уксусная кислота может повторно использоваться для проведения процессов фракционирования древесины или перекачиваться отдельно в подготовленные специальные емкости при помощи химического насоса 6.

Целлюлозу, которая осталась в нутч-фильтре 5, подвергали промывке водой под вакуумом до нейтральной реакции промывных вод. После промывки целлюлозу отжимали под вакуумом для удаления избытка воды. Полученную после промывки целлюлозу с влажностью около 40-45 \% помещали в сушильный шкаф, где производили ее сушку при $(103 \pm 2){ }^{\circ} \mathrm{C}$ до постоянного веса.

Наработанную опытную партию МКЦ массой 5,45 кг помещали в герметичную тару.

\section{Получение опытной партии глюкозного гидролизата}

Наработку опытной партии глюкозного гидролизата из МКЦ проводили по методике, ранее используемой в лабораторных условиях [10].

Из полученной опытной партии целлюлозы отбирали навеску высушенной целлюлозы массой 0,3 кг и загружали в шаровую мельницу-гидролизер объемом 10 л, снабженную перемешивающими шарами.

К загруженной целлюлозе приливали 0,42 л раствора $80 \%$-ной $\mathrm{H}_{2} \mathrm{SO}_{4}$ и герметично закрывали крышку. Гидролиз проводили при атмосферном давлении, температуре $23-25{ }^{\circ} \mathrm{C}$, в течение 50 мин, при постоянном перемешивании. Затем в гидролизер добавили 2,4 л дистиллированной воды для снижения концентрации кислоты, переносили полученную смесь в инвертор с рабочим объемом 60 л, нагревали до заданной температуры $\left(95-100^{\circ} \mathrm{C}\right)$, включали мешалку. Нагрев осуществляли с помощью водяной рубашки реактора. Частота вращения мешалки со-

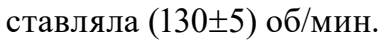

Инверсию (превращение растворимых олигосахаридов в моносахариды) проводили при атмосферном давлении в течение 1 ч. По окончании инверсии установку отключали. Глюкозный гидролизат охлаждали до температуры $30-40{ }^{\circ} \mathrm{C}$.

$$
-274-
$$


Для нейтрализации глюкозного гидролизата в инвертор добавляли 2,4 кг известкового молока, включали мешалку. Известковое молоко готовили заранее в отдельной емкости путем смешения 0,3 кг извести $(85 \% \mathrm{CaO})$ и 2,1 л дистиллированной воды. Нейтрализацию глюкозного гидролиза проводили без дополнительного нагревания смеси в течение 20-30 мин и постоянном перемешивании для предотвращения оседания суспензии $\mathrm{Ca}(\mathrm{OH})_{2}$, а также местного перещелачивания и распада моносахаров. Затем по трубопроводу с помощью насоса суспензию глюкозного гидролиза и известкового молока перекачивали в нутч-фильтр объемом 30 л. В результате нейтрализации образовалось около 2,3 кг $\mathrm{CaSO}_{4}$, выпадающего в осадок. Сульфат кальция выводили из системы фильтрованием глюкозного гидролизата. Фильтрование проводили с применением тканевого фильтра. В системе с использованием водно-кольцевого насоса создавали разряжение на уровне $(-0,9 \div-0,8)$ кгс/ $\mathrm{cm}^{2}$, которое поддерживали на протяжении процесса фильтрования. Сульфат кальция, собранный на фильтре, отправляли на сушку. Измеренная рН отфильтрованного глюкозного гидролизата составила 4,5.

Наработанную опытную партию глюкозного гидролизата 4,2 л помещали в герметичную тару.

\section{Получение опытной партии лигнина}

Наработку опытных партии лигнина из древесины березы проводили по методике, ранее используемой в лабораторных условиях для получения МКЦ [9].

Лигнин осаждали из варочного щелока, образующегося при получении МКЦ методом пероксидной делигнификации древесины березы в среде «уксусная кислота - вода» в присутствии катализатора $\mathrm{TiO}_{2}$.

Варочный щелок получали путем разделения продуктов пероксидной делигнификации древесины березы на жидкую и твердую фазы методом фильтрования на вакуумном нутчфильтре 5 (рис. 1). Вакуум создавали при помощи вакуумного водно-кольцевого насоса 8.

Образующийся жидкий фильтрат перекачивали в нижний реактор 2 для проведения процесса регенерации уксусной кислоты и пероксида водорода.

После регенерации уксусной кислоты из полученного в нижнем реакторе 2 кубового остатка пятикратным разбавлением холодной водой осаждали лигнин. После 12-часовой выдержки раствора осажденный лигнин перекачивали для фильтрования под вакуумом на нутч-фильтр 5. Далее лигнин выгружали из фильтра и подвергали сушке на воздухе в течение 24 ч. Затем воздушно-сухой лигнин направляли для кондиционирования: сушили до постоянной массы в сушильном шкафу при температуре $60{ }^{\circ} \mathrm{C}$. Далее высушенный лигнин измельчали в дисковом истирателе ИДА-175 и просеивали на просевочной машине ГР-30.

Наработанную опытную партию лигнина массой 0,173 кг помещали в герметичную тару.

Физико-химические исследования опытных партий продуктов, полученных

из древесины березы на пилотной установке

При проведении физико-химических исследований опытных партий продуктов из древесины березы применяли методики анализа, описанные в работах [11-13].

Отбор образцов МКЦ для анализа производили методом сокращения и усреднения проб в соответствии с ГОСТ 16189-70. Масса образца составила не менее 100 г. 
При проведении физико-химических исследований опытной партии МКЦ из древесины березы определяли:

- выход МКЦ;

- содержание остаточного лигнина;

- степень полимеризации МКЦ;

- индекс кристалличности МКЦ;

- размер кристаллитов МКЦ.

Рентгенофазовый анализ образца опытной партии МКЦ проводили с использованием дифрактометра ДРОН-3 с излучением $\mathrm{Cu}-\mathrm{K} \alpha(\lambda=0,154$ нм). Съемку дифрактограмм осуществляли в интервале углов $2 \Theta$ от 10 до $60^{\circ}$ с шагом $0,02^{\circ}$ и временем накопления импульсов в точке $4 \mathrm{c}$.

Индекс кристалличности целлюлозы (ИК) рассчитывали из отношения высоты между интенсивностью кристаллического пика $\left(\mathrm{I}_{002}-\mathrm{I}_{\mathrm{AM}}\right)$ и суммарной интенсивности $\left(\mathrm{I}_{002}\right)$ после вычитания фонового сигнала по формуле 1 [14]:

$$
\text { ИК }=\left(\mathrm{I}_{002}-\mathrm{I}_{\mathrm{AM}}\right) /\left(\mathrm{I}_{002}\right),
$$

где $\mathrm{I}_{002}$ - это высота 002 пика $\left(\mathrm{I}_{002}\right) ; \mathrm{I}_{\mathrm{AM}}$ - это высота минимума между 002 и101 пиков.

Средний размер кристаллитов в плоскости (002) определяли по уравнению Шерера:

$$
\mathrm{L}_{002}, \mathrm{~nm}=\left[\left(\beta_{002} \cos \theta_{002} / \lambda\right)^{2}-\left(\delta_{\mathrm{L}} / \mathrm{d}_{\mathrm{L}}\right)^{2}\right]^{-1 / 2},
$$

где $\beta_{002}$ - межплоскостное расстояние, рад; $\theta_{002}$ - угол отражения, рад; $\lambda$ - длина волны рентгеновского источника; $\delta_{\mathrm{L}}$ - параметр, связанный с искажением решетки, перпендикулярной к плоскости (002); $\mathrm{d}_{\mathrm{L}}$ - параметр, связанный с расстоянием между (002) плоскостей кристаллической решетки.

При проведении физико-химических исследований опытной партии глюкозных гидролизатов определяли:

- выход глюкозы;

- содержание примесей;

- количественное содержание фурфурола, 5-гидроксиметилфурфурола и левулиновой кислоты.

Для анализа образец опытной партии лигнина готовили методом сокращения и усреднения проб в соответствии с ГОСТ 16189-70. Масса образца для испытания была не менее 60 г.

При проведении физико-химических исследований опытной партии лигнина определяли:

- элементный состав;

- содержание золы;

- интервал температуры размягчения.

Интервал температуры размягчения опытного образца уксуснокислотного лигнина из древесины березы определяли на приборе Electrothermal IA9100.

Для этого лигнин предварительно высушивали при температуре $80{ }^{\circ} \mathrm{C}$ и измельчали до $\leq 0,2$ мм. Образец подготовленного лигнина помещали в капилляр и осторожным постукиванием перемещали в его запаянный конец. Операцию повторяли до получения на дне капилляра столбика лигнина высотой 3-5 мм. Затем капилляр с лигнином помещали в отверстие

$$
-276-
$$


нагревательного элемента и включали нагрев. Подъем температуры составлял $2-3{ }^{\circ} \mathrm{C}$ в минуту. Началом интервала размягчения считали появление первой жидкой капли в капилляре, окончанием - полное расплавление образца.

\section{Результаты и обсуждение}

При проведении лабораторных исследований [9] процесса получения МКЦ из древесины березы были установлены следующие оптимальные технологические режимы, обеспечивающие получение МКЦ с высоким выходом: температура процесса $100{ }^{\circ} \mathrm{C}$, продолжительность 4 ч, начальные концентрации $\mathrm{H}_{2} \mathrm{O}_{2}-5$ мас. \%, $\mathrm{CH}_{3} \mathrm{COOH} 25$ мас. \%, гидромодуль - 15.

Данные по выходу и составу образцов МКЦ, полученных на пилотной установке и в лабораторных условиях, представлены в табл. 2.

Данные свидетельствуют о том, что выход и состав опытной партии МКЦ практически совпадают с выходом и составом лабораторного образца МКЦ.

На дифрактограммах образца опытной партии МКЦ (1) и лабораторного образца МКЦ (2) из древесины березы (рис. 2) наблюдаются максимумы в области углов 20: 14-16; 22,6; 34-35, относящиеся к отражению от плоскостей 101, 101; 002 и 040 соответственно целлюлозной ячейки, характерной для структурной модификации целлюлозы I [14].

Средняя степень полимеризации (СП), определенная с использованием железовиннонатриевого комплекса (ЖВНК), индекс кристалличности, рассчитанный по отношению интенсивности рассеивания от кристаллической области к общей интенсивности рассеивания рент-

Таблица 2. Выход и состав микрокристаллической целлюлозы (МКЦ) из древесины березы

\begin{tabular}{|c|c|c|c|c|}
\hline \multirow{2}{*}{ Образец МКЦ } & \multirow{2}{*}{$\begin{array}{c}\text { Выход МКЦ, } \\
\text { мас. \%* }\end{array}$} & целлюлоза & лигнин & гемицеллюлозы \\
\cline { 3 - 5 } & 70,0 & 90,3 & 0,9 & 8,4 \\
\hline Опытная партия & 70,2 & 91,9 & 0,7 & 7,1 \\
\hline $\begin{array}{c}\text { Лабораторный } \\
\text { образец }\end{array}$ & & Состав МКЦ, мас. \% ** \\
\hline
\end{tabular}

* от содержания исходной целлюлозы в древесине.

** от массы МКЦ.

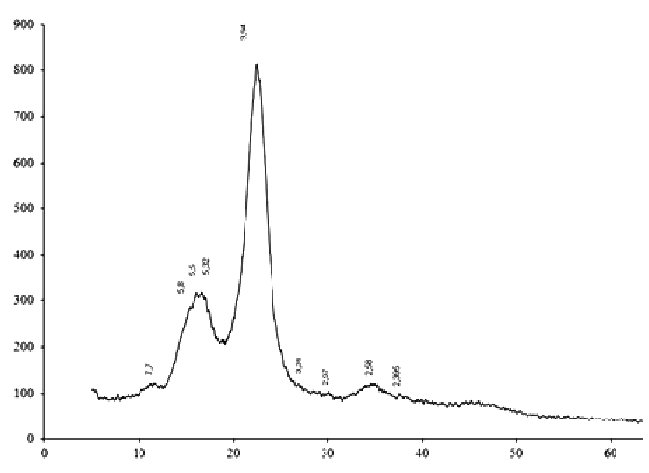

$2 \theta$

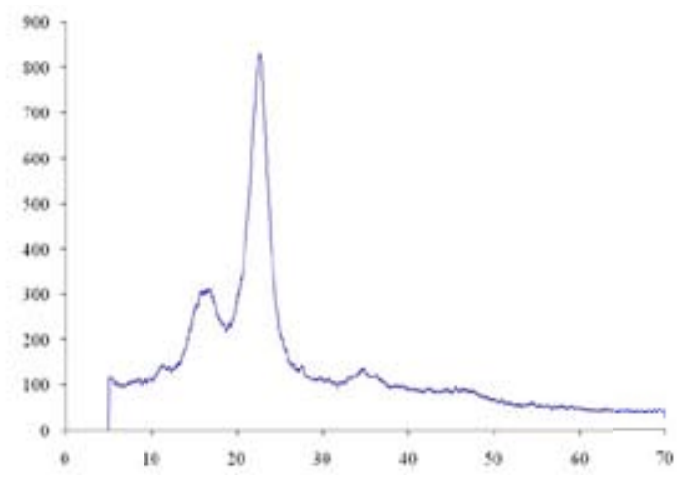

$2 \theta$
(2)

Рис. 2. Дифрактограммы опытной партии МКЦ (1) и лабораторного образца МКЦ (2)

$$
\text { - } 277 \text { - }
$$


геновских лучей, а также средний размер кристаллитов, определенный по уравнению Шерера опытного образца МКЦ и лабораторного образца МКЦ из древесины березы, представлены в табл. 3. Анализ этих результатов показывает, что значения СП, ИК и $\mathrm{L}_{002}$ опытного образца МКЦ мало отличаются от аналогичных показателей лабораторных образцов МКЦ.

Во время лабораторных исследований [10] определены оптимальные значения параметров процесса получения глюкозных гидролизатов, обеспечивающих достижение максимального выхода глюкозы. Установлено существенное влияние на показатели процесса гидролиза температуры, продолжительности и величины гидромодуля. Увеличение температуры, продолжительности и гидромодуля процесса гидролиза приводит к повышению конверсии целлюлозы. На выход глюкозы существенное влияние оказывают продолжительность процесса гидролиза и величина гидромодуля. Установлено, что при температуре $25^{\circ} \mathrm{C}$, продолжительности гидролиза около 50 мин и гидромодуле модуле 1,4 прогнозируемый выход глюкозы составляет около $100 \%$.

Для наработки опытных партий глюкозных гидролизатов из целлюлозы древесины березы выбраны следующие условия гидролиза: 80 мас. \% $\mathrm{H}_{2} \mathrm{SO}_{4}$, температура $25{ }^{\circ} \mathrm{C}$, продолжительность гидролиза 50 мин и гидромодуль 1,4 .

Состав опытной партии глюкозного гидролизата сравнивали с составом образцов, полученных в лабораторных условиях.

На рис. 3 представлены хроматограммы разделения анализируемых компонентов в опытной партии глюкозного гидролизата (1) и в лабораторном образце глюкозного гидролизата (2).

Полученные хроматограммы включают пики всех содержащихся в гидролизате таутомеров моносахаридов.

Результаты проведенных анализов показали, что в оптимальных условиях гидролиза содержание глюкозы в опытной партии глюкозного гидролизата составляет 83,2 \% от массы загруженной целлюлозы.

В табл. 4 приведены сравнительные результаты определения выхода глюкозы в опытной партии глюкозного гидролизата и лабораторном образце гидролизата. Установлено, что выход глюкозы, достигнутый при наработке опытной партии глюкозного гидролизата, близок к выходу глюкозы при получении лабораторного образца гидролизата.

В табл. 5 даны результаты количественного определения наличия микропримесей индивидуальных веществ в опытной партии гидролизата и в лабораторном образце гидролизата.

Установлено, что содержание микропримесей и токсичных компонентов, ингибирующих ферментацию гидролизатов в этанол (фурфурола, 5-ГМФ, левулиновой кислоты), близко в опытной партии и лабораторном образце гидролизата.

Таблица 3. Степень полимеризации $(\mathrm{CП})$, индекс кристалличности (ИК) и размер кристаллитов $\left(\mathrm{L}_{002}\right)$ образцов МКЦ из древесины березы

\begin{tabular}{|l|c|c|c|}
\hline \multicolumn{1}{|c|}{ Образец МКЦ } & СП & ИК & $\mathrm{L}_{002}$, нм \\
\hline Опытная партия & 655 & 0.73 & 3.2 \\
\hline Лабораторный образец & 637 & 0.80 & 3.1 \\
\hline
\end{tabular}




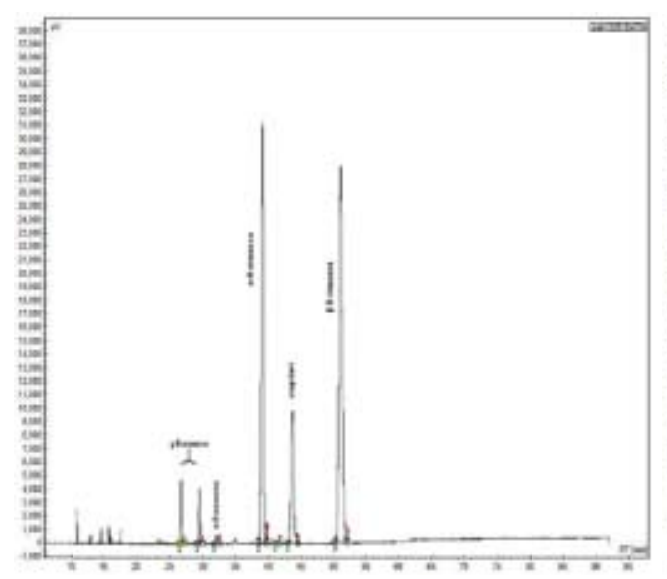

(1)

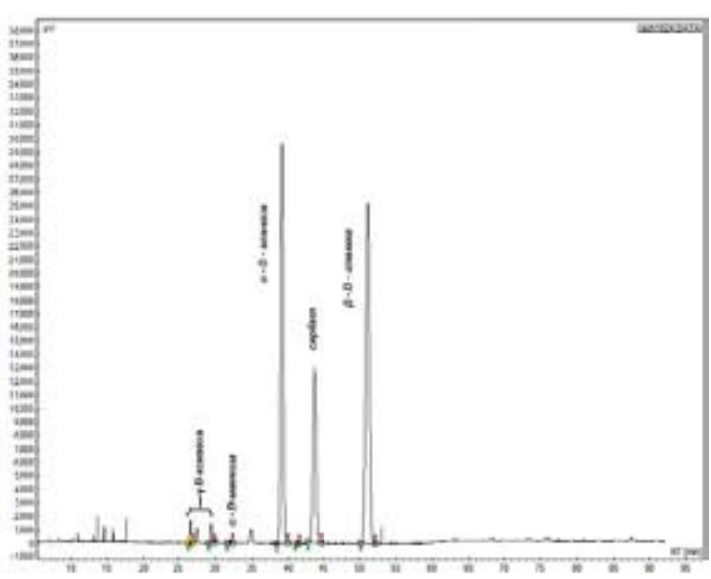

(2)

Рис. 3. Хроматограммы опытной партии глюкозного гидролизата (1) и лабораторного образца глюкозного гидролизата (2), полученные методом ГХ

Таблица 4. Выход глюкозы в глюкозных гидролизатах из целлюлозы березы

\begin{tabular}{|l|c|c|}
\hline \multicolumn{1}{|c|}{ Образец гидролизата } & Ед. изм. & Измеренное значение \\
\hline Опытная партия & мас. $\% *$ & 83,2 \\
\hline Лабораторный образец & мас. $\% *$ & 84,1 \\
\hline
\end{tabular}

* от массы МКЦ.

Таблица 5. Количественное содержание фурфурола, 5-ГМФ и левулиновой кислоты в глюкозных гидролизатах из целлюлозы березы

\begin{tabular}{|c|c|c|}
\hline Образец гидролизата & Наименование соединения & Содержание, мг/мл \\
\hline \multirow{3}{*}{ Опытная партия } & фурфурол & 0,22 \\
\cline { 2 - 3 } & 5-ГМФ & 0,48 \\
\cline { 2 - 3 } & левулиновая кислота & с.к.* \\
\hline \multirow{2}{*}{$\begin{array}{c}\text { Лабораторный } \\
\text { образец }\end{array}$} & фурфурол & 0,16 \\
\cline { 2 - 3 } & 5-ГМФ & 0,46 \\
\hline
\end{tabular}

* следовое количество.

На рис. 4 представлены хроматограммы разделения токсичных компонентов в опытной партии глюкозного гидролизата (1) и в лабораторном образце гидролизата (2).

Проведенные расчеты показали, что в опытной партии глюкозного гидролизата левулиновая кислота содержится в следовых количествах (с.к.), содержание фурфурола составляет 0,22 мг/мл, а 5-ГМФ - 0,48 мг/мл. 
Некоторые характеристики лигнина опытной партии и образца лабораторного лигнина, полученных из древесины березы, приведены в табл. 6 .

Установлено, что элементный состав, зольность и температура размягчения опытной партии лигнина близки к аналогичным характеристикам лабораторного образца лигнина.

МКЦ, получаемая из древесины березы, может использоваться в пищевой промышленности, в фармацевтике и медицине, в производстве косметики в замен МКЦ из хлопка, в качестве кормовой добавки, в химической промышленности, как сырье для получения нанокристаллической целлюлозы, нанокомпозитов, эфиров, сополимера и других востребованных веществ.

Областью практического применения глюкозных гидролизатов из целлюлозы древесины березы является получение пищевой глюкозы, а также ферментативный синтез биоэтанола и других ценных органических продуктов.

Перспективные направления утилизации лигнина, получаемого из древесины березы, это производство энтеросорбентов, нанопористых углеродных материалов, органических и углеродных аэрогелей, связующих для производства древесных плитных материалов и брикетированных биотоплив.

\section{Заключение}

Разработаны технологические принципы комплексной переработки биомассы березы в биотоплива и химические продукты.

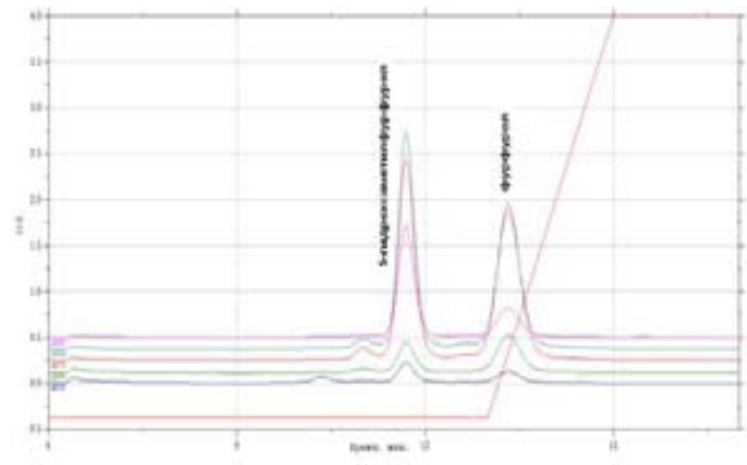

(1)

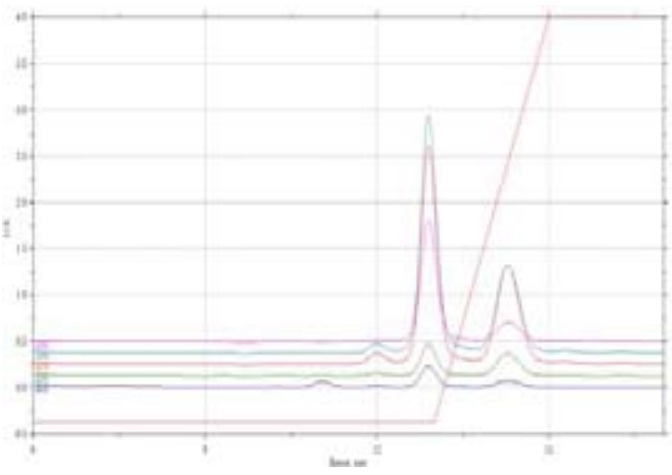

(2)

Рис. 4. Хроматограммы примесей 5-ГМФ и фурфурола в опытной партии гидролизата (1) и лабораторном образце гидролизата (2), полученные методом ВЭЖХ

Таблица 6. Элементный состав, содержание общей золы и интервал температуры размягчения образцов лигнина

\begin{tabular}{|c|c|c|c|c|c|c|c|}
\hline \multirow{2}{*}{ Образец лигнина } & \multicolumn{3}{|c|}{ Элементный состав, мас. \% } & \multicolumn{2}{|c|}{$\begin{array}{c}\text { Атомные } \\
\text { соотношения }\end{array}$} & \multirow{2}{*}{$\mathrm{A}^{\mathrm{daf}}$, мac. $\%$} & \multirow{2}{*}{$\Delta \mathrm{T},{ }^{\circ} \mathrm{C}$} \\
\hline & $\mathrm{C}$ & $\mathrm{H}$ & $\mathrm{O}$ & $\mathrm{H} / \mathrm{C}$ & $\mathrm{O} / \mathrm{C}$ & & \\
\hline Опытная партия & 58,84 & 5,81 & 35,15 & 0,84 & 0,45 & 2,94 & $115-138$ \\
\hline Лабораторный образец & 61,26 & 5,68 & 33,06 & 1,11 & 0,40 & 3,42 & $118-134$ \\
\hline
\end{tabular}


Ключевым процессом в разрабатываемой технологии комплексной переработки биомассы березы является ее фракционирование на полисахариды и лигнин. Их дальнейшая переработка в интегрированном технологическом цикле в биотоплива и ценные химические вещества обеспечивает снижение капитальных затрат на единицу получаемой продукции, позволяет достичь эффектов энерго- и ресурсосбережения и снизить загрязнение окружающей среды.

Разрабатываемая технология комплексной переработки древесины березы дает возможность получать из полисахаридной составляющей древесины биоэтанол, микрокристаллическую целлюлозу (МКЦ), глюкозу, $\mathrm{C}_{5}$-сахара; из лигнина древесины - энтеросорбенты, органические и углеродные аэрогели, нанопористые углеродные материалы; из древесных опилок и лигнинового связующего - брикетированные биотоплива с улучшенными характеристиками.

Указанные продукты интегрированной переработки древесины березы востребованы в энергетике, медицине и ветеринарии, охране окружающей среды и других областях.

Интеграция разработанных авторами методов переработки древесины березы в единый технологический цикл позволяет снизить затраты на производство из древесных отходов энергоносителей (биоэтанол, твердое биотопливо) за счет дополнительного получения ассортимента востребованных рынком продуктов с высокой добавленной стоимостью (микрокристаллическая целлюлоза, органические и углеродные аэрогели, сорбенты).

Для получения из целлюлозы березы качественных гидролизатов для ферментативного синтеза биоэтанола предложено совместить процессы выделения чистой целлюлозы методом пероксидной каталитической делигнификации древесины и кислотно-каталитического гидролиза целлюлозы концентрированной серной кислотой. Это позволило получить из целлюлозы березы без значительных энергозатрат гидролизаты с высоким содержанием глюкозы и с повышенной добракачественностью. Максимальный выход глюкозы (до 88,5 мас. \%) достигнут при гидролизе целлюлозы, полученной в результате интеграции стадий предгидролиза и делигнификации древесины и заключительной обработки щелочью. Содержание нежелательных примесей (ксилозы, 5-ГМФ, фурфурола и левулиной кислоты) в этих гидролизатах незначительно.

На пилотной установке при оптимальных условиях процесса каталитической пероксидной делигнификации древесины березы наработана опытная партия микрокристаллической целлюлозы в количестве 5,45 кг. Показано, что по своим свойствам опытная партия МКЦ не уступает образцам, полученным в лабораторных условиях: выход МКЦ составил более 70 мас. \% при содержании остаточного лигнина менее 1 мас. \%. При этом степень полимеризации опытного образца МКЦ 655, индекс кристалличности 0,73, а размер кристаллитов 3,2 нм.

При оптимальных условиях на пилотной установке наработана опытная партия глюкозного гидролизата объемом 4,2 л из целлюлозы древесины березы. Установлено, что по своим свойствам (показателю выходу глюкозы, наличию примесей и токсичных компонентов, таких как фурфурол, 5-ГМФ, левулиновая кислота) опытная партия глюкозного гидролизата сравнима с образцами, полученными в лабораторных условиях.

На пилотной установке при оптимальных условиях наработана опытная партия лигнина из древесины березы массой 0,173 кг. Показано, что лигнин имеет элементный состав: С - 58,84 мас. \%, Н - 5,81 мас. \%, О - 35,15 мас. \%; зольность 2,94 мас. \% и интервал температу- 
ры размягчения $115-138{ }^{\circ} \mathrm{C}$. По своим характеристикам он может использоваться для получения энтеросорбентов, аэрогелей, нанопористых углеродных материалов.

\section{Исследования выполнены при финансовой поддержке Минобрнауки России (проект RFMEFI60714X 0031).}

\section{Список литературы}

1. Franko Balazs, Galbe Mats, Wallberg Ola. Bioethanol production from forestry residues: A comparative techno-economic analysis. Applied Energy. 2016. V. 184. Р. 727-726.

2. Кузнецов Б.Н., Кузнецова С.А., Яценкова О.В., Данилов В.Г. Получение целлюлозы каталитической делигнификацией древесины пероксидом водорода. Красноярск: Сибирский федер. ун-т, 2014. 146 с. [Kuznetsov B.N., Kuznetsova S.A., Yatsenkova O.V., Danilov V.G. Production of cellulose by catalytic delignification of wood with hydrogen peroxide. Krasnoyarsk: Siberian Federal University, 2014. 146 p. (In Russ.)]

3. Кузнецов Б.Н., Левданский В.А., Кузнецова С.А. Химически продукты из древесной коры. Красноярск: Сибирский федер. ун-т, 2012. 260 с. [Kuznetsov B.N., Levdansky V.A., Kuznetsova S.A., Chemically products from wood bark. Krasnoyarsk: Siberian Federal University, 2012. 260 p. (In Russ.)]

4. Biorefinery Co-Products C., Bergeron D.J., Carrier S. Ramaswamy. United Kingdom: John Wiley \& Sons, 2012. 361 p.

5. Davis S.C., Hay W., Pierce J. Biomass in the energy industry: an introduction. BP p. 1. c, London, UK, 2014.

6. Кузнецов Б.Н., Тарабанько В.Е., Кузнецова С.А. Новые каталитические методы в получении целлюлозы и других химических продуктов из растительной биомассы. Кинетика и катализ, 2008, Т. 49, № 4, С. 541-551. [Kuznetsov B.N., Tarabanko V.E., Kuznetsova S.A. New catalytic methods in the production of cellulose and other chemical products from plant biomass. Kinetics and catalysis, 2008, V. 49, No. 4, P. 541-551 (In Russ.)]

7. Кузнецов Б.Н., Кузнецова С.А., Данилов В.Г., Тарабанько В.Е. Получение химических продуктов из древесины березы методами каталитического окисления и кислотного катализа. Химия в интересах устойчивого развития, 2005, Т. 13, С. 531-539. [Kuznetsov B.N., Kuznetsova S.A., Danilov V.G., Tarabanko V.E. Production of chemical products from birch wood using catalytic oxidation and acid catalysis. Chemistry for Sustainable Development, 2005, V. 13, P. 531-539 (In Russ.)]

8. Кузнецова С.А., Данилов В.Г., Яценкова О.В. и др. Экологически безопасный процесс получения целлюлозы из древесины березы. Журнал Сибирского федерального университета. Химия. 2008. Т. 1. № 2. C. 181-189. [Kuznetsova S.A., Danilov V.G., Yatsenkova O.V. Ecologically safe process of obtaining cellulose from birch wood. Journal of the Siberian Federal University. Chemistry. 2008. T. 1. No. 2. C. 181-189. (In Russ.)]

9. Гарынцева Н.В, Судакова И.Г., Кузнецов Б.Н. Изучение каталитической делигнификации древесины березы пероксидом водорода при атмосферном давлении. Журнал Сибирского федерального университета. Химия. 2015. Т. 8. № 3. С. 422-429. [Garyntseva N.V., Sudakova I.G., Kuznetsov B.N. The study of catalytic delignification of birch wood with hydrogen 
peroxide at atmospheric pressure. Journal of the Siberian Federal University. Chemistry. 2015. T. 8. № 3. P. 422-429. (In Russ.)]

10. Яценкова О.В., Пен Р.З., Скрипников А.М., Береговцова Н.Г., Кузнецов Б.Н. Оптимизация процесса гидролиза микрокристаллической целлюлозы концентрированной серной кислотой. Химия в интересах устойчивого развития 2016. № 24, C. 811-819. [Yatsenkova O.V., Pen R.Z., Skripnikov A.M., Beregovtsova N.G., Kuznetsov B.N. Optimization of the process of hydrolysis of microcrystalline cellulose with concentrated sulfuric acid. Chemistry for Sustainable Development 2016. No. 24, P. 811-819. (In Russ.)]

11. Оболенская А.В., Ельницкая 3.П., Леонович А.А. Лабораторные работы по химии древесины и целлюлозы. М.: Экология, 1991. 320 с. [Obolenskaya A.V., Elnitskaya Z.P., Leonovich A.A. Laboratory work on wood chemistry and cellulose: a textbook for high schools. M.: Ecology, 1991. 320 p. (In Russ.)]

12. Азарова И.Н., Барсегян С.С., Барам Г.И. Новые возможности высокоэффективной жидкостной хроматографии: Базы данных “ВЭЖХ-УФ”. Хроматография на благо России. Под ред. Курганова А.А. М.: «Граница», 2007. C. 653-665. [Azarov I.N., Barseghyan S.S., Baram G.I. New possibilities of high-performance liquid chromatography: Data bases "HPLC-UV". Chromatography for the Benefit of Russia» Edited by Kurganov A.A. M.: Boundary, 2007. P. 653-665. (In Russ.)]

13. Барам. Г.И. Развитие метода микроколоночной высокоэффективной жидкостной хроматографии и его применение для исследования объектов окружающей среды. В книге: 100 лет хроматографии. Отв. ред. Б.А. Руденко. М.: Наука, 2003. С. 32-45. [Baram. G.I. Development of the method of micro-column high-performance liquid chromatography and its application for the study of environmental objects. 100 Years of Chromatography. Edited by B.A. Rudenko. Moscow: Nauka, 2003. P. 32-45. (In Russ.)]

14. Park S., Baker J.O., Himmel M.E. Parilla P.A., Jonson D.K. Cellulose crystallinity index: measurement techniques and their impact on interpreting cellulose performance. Biotechnology for Biofuels. 2010. V. 3. P. 10. 